\title{
Cointegration analysis of indirect taxes and economic growth in the Republic of Serbia
}

\section{Коинтеграциона анализа индиректних пореза и економског раста у Републици Србији}

\author{
Branimir Kalaš* \\ University of Novi Sad, Faculty of Economics, Subotica, Serbia, branimir.kalas@ef.uns.ac.rs \\ Vera Mirović \\ University of Novi Sad, Faculty of Economics, Subotica, Serbia, vera.mirovic@ef.uns.ac.rs \\ Jelena Andrašić \\ University of Novi Sad, Faculty of Economics, Subotica, Serbia, jelena.andrasic@ef.uns.ac.rs
}

\begin{abstract}
This research examines the relationship between indirect taxes and gross domestic product per capita in the Republic of Serbia from 2005 to 2019. The aim of this paper is to evaluate the long-run relationship between value added tax, excises and gross domestic product per capita based on Johansen cointegration test. The empirical analysis includes descriptive statistics, unit root test, cointegration test and FMOLS model. The results reveal a long-run relationship between indirect taxes such as value added tax and excises and the gross domestic product per capita in the Republic of Serbia for the observed period. Empirical findings confirm that revenues of value added tax and excises have positive and significant effect on the gross domestic product per capita in the long-run.
\end{abstract}

Keywords: value added tax, excises, economic growth, cointegration, Republic of the Serbia JEL classification: C32, H20, 040

Сажетак: Истраживање испитује однос између индиректних пореза и бруто домаћег производа по глави становника у Републици Србији од 2005. до 2019. године. Циљ овог рада је оценивање дугорочне везе између пореза на додату вредност, акциза и бруто домаћег производа по глави становника на основу Јохансеновог теста коинтеграције. Емпиријска анализа укључује дескриптивну статистику, тест јединичног корена, тест коинтеграције и FMOLS модел. Резултати указују на дугорочну везу између индиректних пореза као што су порез на додату вредност и акциза и бруто домаћег производа по глави становника у Републици Србији за посматрани период. Емпиријски налази потврђују да порез на додату вредност и акцизе имају позитиван и значајан ефекат на бруто домаћи производ по глави становника у дугом року.

Кључне речи: порез на додату вредност, акцизе, економски раст, коинтеграција, Република Србија JEЛ класификација: C32, Н20, 040

\footnotetext{
Corresponding author
} 


\section{Introduction}

Taxes reflect economic expression of the state existence (Andrašić et al. 2018) where taxation involves an exchange relationship between citizens and government (Castañeda Rodríguez, 2018). In modern government, taxes play an essential role in their programs and they are a powerful tool for achieving main goals in the economy (Kalaš et al. 2018). Collection of taxes allows the government to create maximum development projects for the public interest and improve the basic infrastructure of health, education, as well as people's quality of life (Streimikiene et al. 2018). For the optimal design of taxes it is essential to be aware of its built-in revenue capacity which implies that automatic revenues respond to changes in the economy (Sanz-Sanz et al. 2016). Government expenditures are supposed to be financed by increasing taxes, changing the consumption of expenditures or raising public debt (Iyidoğan et al. 2017).

It is very important for the tax policy holders to determine potential effects that changes in individual tax forms will have on overall economic performance (Grdinić et. al 2017). Hodžić et al. (2018) indicate that tax system should be business-friendly so it can have an essential positive effect on the economy. Milasi and Waldmann (2017) argue that raising top marginal tax rates which are below their growth maximum has the greatest positive effect on growth when the related additional revenues are used to finance public expenditures and reduce budget deficits. Feher et al. (2019) argue that value added tax is the most effective tax during the crisis to reduce budget deficits.

The structure of this paper is as follows. After the introduction, there is theoretical background about relationship between economic growth and taxes with focus on indirect taxes such as value added tax and excises. The third section includes an analysis of value added tax and excises in the Republic of Serbia from 2005 to 2019. The greatest part of this paper includes empirical analysis and results which consist of descriptive statistics, ADF test, Johansen cointegration test, as well as FMOLS model in order to identify long-run effect of indirect taxes on the gross domestic product per capita in the Republic of Serbia.

\section{Literature review}

Many empirical studies suggest that there is a robust link between tax structure and economic growth (Xing, 2011). Prichard (2016) highlighted that direct taxes such as personal and corporate income tax are bad for growth compared to indirect taxes. On the other hand, there are many empirical studies that have estimated the relationship between indirect taxes and economic growth (Alm \& El-Gannainy, 2012; Li \& Lin, 2015; Simionescu et al. 2016; Loganathan et al. 2017; Kalaš \& Milenković, 2017; McNabb, 2018; Dobranschi \& Nerudová, 2018).

Alm and El-Ganainy (2012) examined relationship between value added tax and consumption in fifteen EU countries for the period 1961-2005. Results of dynamic panel GMM-System estimator indicated that effective value added tax rate is negatively correlated with the consumption. Namely, a one percentage point increase in the tax rate leads to about a one percent reduction in the consumption. 
Around that, Benkovskis and Fadejeva (2014) investigated the effect of value added tax rate on inflation in Latvia using the CPI microdata provided by the Central Statistical Bureau of Latvia. Their findings reflect that changes in the VAT rate could have an essential effect on price movement in Latvia.

Li and Lin (2015) examined the impact of sales tax on economic growth in the United States for the period 1960-2013. Results of empirical study confirmed that economic growth in the United States responds negatively to sales tax in the long run, although it produces positive impact in the short run. Empirical analysts Simionescu et al. (2016) analyzed the impact of standard value added tax rate on economic growth in Bulgaria, Czech Republic, Hungary, Poland and Romania for the period 1995-2005. Their findings showed bidirectional causality between these variables and negative effect of value added tax rate on economic growth in most observed countries. Namely, value added tax rate had positive impact only in Hungary, while other countries recorded lower gross domestic product rates.

Loganathan et al. (2017) researched the nexus between taxation and economic growth for emerging Asian countries, namely China, India, Indonesia, Republic of Korea, Malaysia and Thailand for the period 1990-2014. Their findings indicate bidirectional causality between growth and taxation, as well as unidirectional causality from stock traded to taxation in observed countries. Kalaš and Milenković (2017) examined the relationship between value added tax and economic growth measured by gross domestic product rate in the Republic of Serbia for the period 2005-2014. Their findings indicated strong and positive correlation between observed variables, which implies that revenues of value added tax are significantly related to gross domestic product rate in the Republic of Serbia. $\mathrm{McNabb}$ (2018) analyzed panel relationship between tax structure and economic growth for 100 countries and confirmed that revenue-neutral increases in income taxes are related to lower GDP in the long-run. On the other hand, results showed that revenue-neutral reductions in trade taxes have not always had positive impact on economic growth.

Dobranschi and Nerudová (2018) analyzed the effect of value added tax and excise duties in the European Union and their findings indicated that tax burden resulting from ad valorem and ad unit taxes imposed on goods tend to be borne more by the final consumers than by the seller. On the other hand, the excise duty burden is close to fully shifted towards consumers. Using the common correlated effects (CCE) panel cointegration approach, Durusu-Ciftci et al. (2018) estimated the long-run effect of taxes on economic development in thirty OECD countries for the period 1995-2016. Their findings indicated that only consumption tax has a statistically significant negative impact on long-run income.

Laković et al. (2019) argue that an increase in excise taxes could be a very efficient tool in decreasing the adverse effect on household members' health, productivity and budget. Luong and $\mathrm{Vu}$ (2020) highlighted that excises are identified for specific goods and services that are not encouraged due to their bad effects on health. 


\section{Methodology and data}

This research analyzes value added tax and excises as two most generous taxes in the Republic of Serbia. The analysis included annual data available for the Republic of Serbia and measures these taxes in local currency value (RSD). On the other hand, economic growth is measured by gross domestic product per capita which is also expressed in local currency value (RSD).

The data was obtained from the Ministry of Finance of the Republic of Serbia and the International Monetary Fund. Likewise, the data series is annual, ranging from 2005 to 2019 for 15 years.

FMOLS was proposed by Phillips and Hansen (1990) and this model was applied to estimate the long-run effect of value added tax and excises on gross domestic product per capita in the Republic of Serbia since cointegration test confirmed the presence of long-run relationship between selected variables.

$$
L \mathrm{GDPpc}_{i t}=\alpha+\beta_{1} \mathrm{LVVAT}_{i t}+\beta_{2} \mathrm{LEXC}_{i t}++\varepsilon
$$

where $\mathrm{i}$ refers to the cross-section, $\mathrm{t}$ refers to the time, $\alpha$ refers to the constant term, LGDPpc refers to logarithmic value of gross domestic product per capita, LVAT - logarithmic value of value added tax, LEXC - logarithmic value of excises and $\varepsilon$ refers to the error or residual term.

\section{Empirical analysis and results}

This segment includes analysis trend of gross domestic product per capita, as well as indirect taxes such as value added tax and excises in the Republic of Serbia for the period 2005-2019. After presenting descriptive statistics of observed variables, we proceed to ADF unit root test, as well as Johansen cointegration test. Finally, a fully modified ordinary least Squares model is presented in order to determine the long-run effect of value added tax and excises on the gross domestic product per capita in the Republic of Serbia.

Table 1: Descriptive statistics

\begin{tabular}{|l|c|c|c|}
\hline Variable & GDPpc & VAT & EXC \\
\hline Mean & 515668 & 368265 & 186734 \\
\hline Median & 529242 & 367472 & 181097 \\
\hline Maximum & 753544 & 550563 & 306546 \\
\hline Minimum & 248207 & 216008 & 71275 \\
\hline Std. Dev. & 155688 & 100381 & 77665 \\
\hline Skewness & -0.1576 & 0.1518 & 0.0645 \\
\hline Kurtosis & 1.9467 & 2.0626 & 1.7274 \\
\hline
\end{tabular}

Source: Authors calculation

Results of descriptive analysis show that average gross domestic product per capita was 515668 RSD for the period 2005 to 2019. The highest value of gross domestic product per capita was recorded in 2019, when it was 753544 RSD, while the smallest level was 
identified in 2005 (248207 RSD). On the other hand, average revenues of value added tax are 368265, where this tax form represents the most generous tax in the Republic of Serbia. Excises are second tax form which contribute to budget more than other tax in the Republic of Serbia. It is necessary to highlight that value added tax and excises have share more than $60 \%$ in the total tax structure and manifest two most important tax in the Republic of Serbia.

Table 2: Augmented Dicky-Fuller (ADF) test

\begin{tabular}{|l|l|l|l|l|}
\hline Variable & Level & First difference & $\begin{array}{l}\text { Critical value } \\
(5 \%)\end{array}$ & I(D) \\
\hline Intercept & & & & \\
\hline GDPpc & -1.315185 & -3.58544 & $5 \%$ & I (1) \\
\hline VAT & 1.277150 & -4.328078 & $5 \%$ & I (1) \\
\hline EXC & 0.150827 & -4.071807 & $5 \%$ & I (1) \\
\hline
\end{tabular}

Source: Authors calculation

The results of ADF test reflect that selected variables are not stationary at level, but variables are stationary at first difference. It implies that null hypothesis can be rejected at the $5 \%$ level of significance when applying each variable at first difference. We can conclude that these variables are stationary at first difference and integrated of order one process or I (1).

Table 3: Unrestricted Cointegration Rank Test (Trace)

\begin{tabular}{|l|c|c|c|c|}
\hline $\begin{array}{l}\text { Hypothesized No. } \\
\text { of CE(s) }\end{array}$ & Eigenvalue & Trace Statistic & Critical Value & Prob.** \\
\hline None* & 0.903208 & 49.93758 & 29.7907 & 0.0001 \\
\hline At most 1* & 0.785451 & 21.91532 & 15.49471 & 0.0047 \\
\hline At most 2 & 0.249532 & 3.444694 & 3.84146 & 0.0635 \\
\hline
\end{tabular}

Source: Authors calculation

Table 3 shows that there is long run relationship between gross domestic product per capita, value added tax and in the Republic of Serbia for the period 2004-2019. The result of Johansen cointegration test shows that these variables converge in the long-run.

Table 4: Unrestricted Cointegration Rank Test (Maximum Eigenvalue)

\begin{tabular}{|l|c|c|c|c|}
\hline $\begin{array}{l}\text { Hypothesized No. } \\
\text { of CE(s) }\end{array}$ & Eigenvalue & Trace Statistic & Critical Value & Prob.** \\
\hline None* & 0.903208 & 28.02226 & 21.13162 & 0.0046 \\
\hline At most $1 *$ & 0.785451 & 18.47062 & 14.26460 & 0.0102 \\
\hline At most 2 & 0.249532 & 3.44694 & 3.84146 & 0.0635 \\
\hline
\end{tabular}

Source: Authors calculation

The long-run relationship exists at 5\% level of significance according to the trace test statistics which implies that there is existence of long-run relationship between indirect taxes and gross domestic product per capita in the Republic of Serbia. 
Table 5: Fully Modified Least Squares (FMOLS model)

\begin{tabular}{|l|l|l|l|l|}
\hline Variable & Coefficient & Std. Error & t-Statistic & Prrob. \\
\hline$\Delta$ VAT & 0.590405 & 0.147328 & 3.939530 & 0.0028 \\
\hline$\Delta$ EXC & 0.587636 & 0.144250 & 4.073733 & 0.0022 \\
\hline C & -0.011280 & 0.008642 & -1.305348 & 0.2210 \\
\hline R-squared & & 0.722609 \\
\hline & Adjusted R-squared & 0.627131 \\
\hline S.E. of regression & 0.013487 \\
\hline Long-run variance & 0.000101 \\
\hline Mean dependent var & 0.031412 \\
\hline S.D. dependent var & 0.017819 \\
\hline Sum squared resid & 0.001819 \\
\hline
\end{tabular}

Source: Authors calculation

Table 5 shows Fully Modified Least Squares model which examined the long-run impact of value added tax and excises on gross domestic product per capita in the Republic of Serbia. From the FMOLS results above, the adjusted R-squared of 0.63 indicates that these variables jointly explain $62.71 \%$ variations in the gross domestic product per capita in the Republic of Serbia. The probability value of the individual explanatory variable reveals that value added tax and excises are statistically significant at level of 5\%. Namely, in the long run, $1 \%$ increase of revenues by these taxes would rise gross domestic product per capita for $0.59 \%$ and $0.58 \%$.

\section{Conclusion}

This research investigates the relationship between indirect taxes such as value added tax and excises and gross domestic product per capita in the Republic of Serbia for the period 2005 to 2019 . The aim of this paper is to estimate the long-run relationship between these variables based on Johansen cointegration test.

The analysis includes descriptive statistics, unit root test, cointegration test, as well as, fully modified ordinary least squares model. Empirical results reveal long-run relationship between indirect taxes and gross domestic product per capita in the Republic of Serbia for the analyzed period. Empirical findings confirm that revenues of value added tax and excises have positive and statistically significant effect on economic growth measured by gross domestic product per capita in the long-run. Results of FMOLS model reflect that a $1 \%$ increase in revenues of indirect taxes increases GDPpc for $0.59 \%$ (in case of value added tax growth) and $0.58 \%$ (in case of excises growth). The contribution of the research is presented in fact that we have ensured the quantitative measurement of relationship between indirect taxes and gross domestic product per capita in the long-run. The paper has provided a better understanding of the relationship between this type of taxes and economic growth, as well as, their effect on gross domestic product per capita in the long-run. 


\section{References}

Alm, J., \& El-Ganainy, A. (2012). Value-added taxation and consumption. International Tax and Public Finance, 20(1), 105-128. Doi: https://doi.org/10.1007/s10797-012-9217-0

Andrašič, J., Kalaš, B., Mirović, V., Milenković, N., \& Pjanić, M. (2018). Econometric modelling of tax impact on economic growth: Panel evidence from OECD countries. Economic Computation and Economic Cybernetics Studies and Research, 52(4), 211-226, Doi: https://doi.org/10.24818/18423264/52.4.18.14

Benkovskis, K., \& Fadejeva, L. (2014). The effect of VAT rate on inflation in Latvia: evidence from CPI microdata. Applied Economics, 46(21), 2520-2533. Doi: https://doi.org/10.1080/00036846.2014.904492

Castañeda Rodríguez, V. M. (2018). Tax determinants revisited. An unbalanced data panel analysis. Journal of Applied Economics, 21(1), 1-24. Doi: https://doi.org/10.1080/15140326.2018.1526867

Dobranschi, M., \& Nerudová, D. (2018). Tax collision: the effect of VAT and excise duties on the retail price of unleaded gasoline. Ekonomický časopis, 66(7), 643-664.

Durusu-Ciftci, D., Gokmenoglu, K. K., \& Yetkiner, H. (2018). The heterogeneous impact of taxation on economic development: New insights from a panel cointegration approach. Economic Systems, 42(3), 503-513. Doi: https://doi.org/10.1016/j.ecosys.2018.01.001

Feher, A., Condea, B.V. \& Harangus, D. (2019). Impact of harmonization on the implicit tax rate of consumption. Prague Economic Papers, 28(4), 449-464. Doi: https://doi.org/10.18267/j.pep.705

Grdinić, M., Drezgić, S., \& Blažić, H. (2017). An empirical analysis of the relationship between tax structures and economic growth in CEE countries. Ekonomický časopis, 65(5), 426-447.

Hodžić, S., Keček, D., \& Mikulić, D. (2018). Sectoral linkages of taxes: An input-output analysis of the Croatian economy. Ekonomický časopis, 66(6), 598-620.

Iyidoğan, P., Balikcioğlu, E., \& Yilmaz, H. (2017). The tax effects of health expenditures on aging economies: empirical evidence on selected OECD countries. Romanian Journal of Economic Forecasting, 20(1), 116-127.

Kalaš, B., \& Milenković, N. (2017). The role of value added tax in the economy of Serbia. Ekonomika, 63(2), 69-78.

Kalaš, B., Mirović, V., \& Andrašić, J. (2018). Empirical analysis of value added tax and inflation rate: Tuckey's HSD test in selected Western Balkan countries. Ekonomika, 64(2), 99-109.

Laković, T., Mugoša, A., Čizmović, M., \& Radojević, G. (2019). Impact of taxation policy on household spirit consumption and public-finance sustainability. Sustainability, 11(20), 1-15. Doi: https://doi.org/10.3390/su11205858 
Li, J.F., \& Lin, Z.X. (2015). The impact of sales tax on economic growth in the United States: an ARDL bound testing approach. Applied Economic Letters, 22(15), 1262-1266. Doi: https://doi.org/10.1080/13504851.2015.1023933

Loganathan, N., Taha, R., Ahmad, N., \& Subramaniam, T. (2017). Taxation, growth and the stock traded nexus in emerging Asian countries: heterogeneous and semi-parametric panel estimates. Economic Research-Ekonomska istraživanja, 30(1), 566-580. Doi: https://doi.org/10.1080/1331677x.2017.1305789

Luong, L. \& Vu, L.H. (2020). Impacts of excise taxation on non-alcoholic beverage consumption in Vietnam. Sustainability, 12(3), 1-13. Doi: https://doi.org/10.3390/su12031092

McNabb, K. (2018). Tax structure and economic growth: new evidence from the government revenue dataset. Journal of International Development, 30(2), 173-205. Doi: https://doi.org/10.1002/jid.3345

Milasi, S. \& Waldmann, R.J. (2017). Top marginal taxation and economic growth. Applied Economics, 50(19), 2156-2170. Doi: https://doi.org/10.1080/00036846.2017.1392001

Phillips, P. C. B., \& Hansen, B. E. (1990). Statistical inference in instrumental variables regression with I(1) processes. Review of Economics Studies, 57(1), 99-125. Doi: https://doi.org/10.2307/2297545

Prichard W, Goodall A, \& Cobham A. (2014). The ICTD Government Revenue Dataset. In: ICTD Working Paper 19. International Centre for Tax and Development: Brighton.

Sanz-Sanz, J. F., Castañer-Carrasco, J. M., \& Romero-Jordán, D. (2016). Consumption tax revenue and personal income tax: analytical elasticities under non-standard tax structures. Applied Economics, 48(42), 4042-4050. Doi: https://doi.org/10.1080/00036846.2016.1150951

Simionescu, M., \& Albu, L.L. (2016). The impact of standard value added tax on economic growth in CEE-5 countries: econometric analysis and simulations. Technological and Economic Development of Economy, 22(6), 850-866. Doi: https://doi.org/10.3846/20294913.2016.1244710

Streimikiene, D., Raheem Ahmed, R., Vveinhardt, J., Ghauri, S. P., \& Zahid, S. (2018). Forecasting tax revenues using time series techniques - a case of Pakistan. Economic Research-Ekonomska Istraživanja, 31(1), 722-754. Doi: https://doi.org/10.1080/1331677x.2018.1442236

Urban, I. Čok, M., \& Verbič, M. (2019). The burden of labour taxation in Croatia, Slovenia and Slovakia in the period 2011-2017. Economic Research-Ekonomska istraživanja, 32(1), 1430-1456. Doi: https://doi.org/10.1080/1331677X.2019.1638291

Xing, J. (2011). Tax structure and growth: How robust is the empirical evidence? Economic Letters, 117(1), 379-382. Doi: https://doi.org/10.1016/j.econlet.2012.05.054 